\title{
Altered Na, K-ATPase mRNA Expression in Spontaneously Hypertensive Rats
}

\author{
Yoshio Tsuruya, Uichi Ikeda, Keiji Yamamoto, Yoshitane Seino, Hitoshi Ebata, Yukihiro Hojo, \\ Kiyoshi Kawakami*, and Kazuyuki Shimada
}

\begin{abstract}
We investigated the expression of $\mathrm{Na}$, K-ATPase $\alpha$ and $\beta$ isoform mRNAs in spontaneously hypertensive rat (SHR) hearts, aortae and kidneys, compared with findings in normotensive Wistar-Kyoto rat (WKY), to obtain insight into the role of these isoforms in the development of hypertension in SHR. We used 4-, 8-, and 16-week-old SHR and WKY. Systolic blood pressure was recorded by tail sphygmomanometry. The expression of Na, K-ATPase $\alpha$ and $\beta$ isoform mRNAs was analyzed by Northern blot hybridization, using isoform specific cDNA probes. In the ventricles, pre-hypertensive 4-week-old SHR showed a significant 3 to 4-fold increase in the $\alpha 1$ and $\alpha 2$ isoform mRNA accumulation compared with age-matched WKY. The $\alpha 3$ isoform mRNA expression was detected only in 4-week-old SHR hearts. The pattern of $\beta 1 \mathrm{mRNA}$ expression resembled that of $\alpha 1$ or $\alpha 2 \mathrm{mRNAs}$, and a significant 7-fold increase was observed in 4-week-old SHR compared with age-matched WKY. In the aortae, the $\alpha 1$ and $\alpha 2$ isoform mRNAs were expressed, and 4-week-old SHR exhibited a significant 5-fold increase in the $\alpha 1$ and $\alpha 2$ isoform mRNA levels compared with age-matched WKY. In the kidneys, only the $\alpha 1$ isoform mRNA was expressed, and that of SHR showed a significant 2-fold increase compared with age-matched WKY. We conclude that the expression of $\mathrm{Na}$, K-ATPase $\alpha$ and $\beta$ isoform mRNAs is significantly increased in the hearts, aortae and kidneys of SHR before the onset of hypertension. These findings suggest that, in this model, the altered expression of $\mathrm{Na}$, K-ATPase gene is an early, if not a primary, event in the development of hypertension. (Hypertension Res 1993; 16: 269-274)
\end{abstract}

Key Words: Na, K-ATPase, Na, K-pump, mRNA, gene expression, spontaneously hypertensive rat

$\mathrm{Na}$, K-ATPase (Na, K-pump), a ubiquitous transmembrane protein, plays an important role in regulating intracellular $\mathrm{Na}^{+}$and $\mathrm{K}^{+}$levels. This functional enzyme is composed of two subunits, a catalytic $\alpha$ subunit $(M r=110,000)$, and a glycosylated $\beta$ subunit $(M r=35,000)$. It is generally agreed that non-vectorial functions of $\mathrm{Na}, \mathrm{K}-\mathrm{ATPase}$, such as ATPase activity and cardiac glycoside binding, are localized to the $\alpha$ subunit. At least three $\alpha$ subunit isoforms, $\alpha 1, \alpha 2$ and $\alpha 3$, have been characterized in rats (1) and humans (2) by cDNA cloning and sequencing. Although the functional role of the $\beta$ subunit is unknown, two types of $\beta$ subunit isoforms, $\beta 1$ and $\beta 2$, have also been identified (3-5). The functional significance of the multiple $\alpha$ isoforms is not clear, although specific differences in sensitivity to cardiac glycosides inhibition and affinity to intracellular $\mathrm{Na}^{+}$concentration have been reported $(6,7)$. The mRNA level of the $\alpha$ isoform varies among different tissues and stages of development (8). For example, in the rat heart, the $\alpha 1$ isoform mRNA is the major isoform expressed throughout all developmental stages, while the $\alpha 2$ isoform mRNA is present primarily in juvenile and adult hearts, and the $\alpha 3$ isoform mRNA is found mainly in fetal and neonatal hearts.

The spontaneously hypertensive rat (SHR) is a genetic model of hypertension whose intracellular $\mathrm{Na}^{+}$levels might be increased $(9-11)$ which is assumed to contribute to the pathogenesis of hypertension. Previous studies on Na, K-ATPase in SHR tissues have been on measurements of $\mathrm{Na}, \mathrm{K}$ ATPase activity or of ouabain binding sites, and various conflicting results have been obtained (12-19). In this study, we investigated the expression of $\mathrm{Na}$, $\mathrm{K}$-ATPase $\alpha$ and $\beta$ isoform mRNAs in SHR hearts, aortae and kidneys, compared with findings in normotensive Wistar-Kyoto rat (WKY), to obtain insight into the role of these isoforms in the development of hypertension in SHR.

\section{Methods}

\section{Materials}

SHR and WKY were purchased from Charles River Japan and fed normal rat chow throughout the

From the Departments of Cardiology, and *Biology, Jichi Medical School, Tochigi, Japan.

Supported in part by research grants of the Ministry of Education, Culture and Science of Japan (\#5770477, \#5670632), the Study Group of Molecular Cardiology, and the Asahi Life Welfare Foundation.

Address for Reprints: Uichi Ikeda, M.D., Department of Cardiology, Jichi Medical School, Minamikawachi-Machi, Tochigi 329-04, Japan.

Received June 10, 1993; accepted in revised form July 23, 1993. 
study. Systolic blood pressure was recorded by tail sphygmomanometry.

\section{Northern Blot Analysis}

Total RNA was isolated from SHR and WKY left ventricles, aortae, and kidneys by the guanidine isothiocyanate-cesium chloride (GITC-CsCl) method $(20,21)$. Equal amounts of total RNA (5-15 $\mu \mathrm{g})$ were size-fractionated by electrophoresis on denaturing $1.0 \%$ agarose/formaldehyde gels and transferred to nylon membranes (Hybond $\mathrm{N}^{+}$, Amersham, UK). Hybridization was performed for $24 \mathrm{~h}$ at $65^{\circ} \mathrm{C}$ with $\mathrm{Na}, \mathrm{K}$-ATPase $\alpha 1, \alpha 2, \alpha 3$ and $\beta 1$ isoform specific cDNA probes (specific activity $>1 \times$ $10^{8} \mathrm{cpm} / \mu \mathrm{g}$ DNA) labeled with ${ }^{32} \mathrm{P}-\mathrm{dCTP}$ (Amersham, UK), using a multiprime DNA labeling kit (Amersham, UK). The $\alpha 1$ cDNA probe consisted of a $2.2 \mathrm{~kb}$ Nco restriction fragment (1). The $\alpha 2$ cDNA probe consisted of a $2.9 \mathrm{~kb}$ fragment restricted by Sac I (1). The $\alpha 3$ cDNA probe consisted of a $1.6 \mathrm{~kb}$ Sac I-Eco RI restriction fragment (1). The $\beta 1$ cDNA probe consisted of a $0.9 \mathrm{~kb}$ Pst I restriction fragment (3). Following hybridization, filters were washed once in 2 XSSPE $(1 \times$ SSPE contains 150 mmol/1 $\mathrm{NaCl}, 10 \mathrm{mmol} / 1 \mathrm{NaH}_{2} \mathrm{PO}_{4}$ and $1 \mathrm{mmol} / 1$ EDTA) with $0.1 \%$ SDS for $15 \mathrm{~min}$ at room temperature and then twice in 1xSSPE with $0.1 \%$ SDS for $15 \mathrm{~min}$ at $65^{\circ} \mathrm{C}$. Filters were exposed to Kodak XAR-5 film for $1-2$ days at $-80^{\circ} \mathrm{C}$ with intensifying screens. Radioactivity was quantitated by densitometric scanning (Immunomedica Image Analyzer TIF-64, Japan) and normalized on the basis of $18 \mathrm{~S}$ or $28 \mathrm{~S}$ rRNA to correct for RNA loading.

\section{Statistical Analysis}

Data are reported as mean \pm SE. Statistical analysis was performed using the unpaired $t$-test, two-tail method, with $p$ values less than 0.05 considered statistically significant.

\section{Results}

Systolic blood pressure (SBP) of the 4-week-old SHR was $119 \pm 2.3 \mathrm{mmHg}$, not significantly different from that of the age-matched WKY $(117 \pm 3.5$ $\mathrm{mmHg}$ ) (Fig. 1). However, at 8 weeks of age, the SBP of SHR significantly exceeded that of WKY $(177 \pm 1.0$ vs. $141 \pm 1.3 \mathrm{mmHg} ; n=12, p<0.01)$. From this analysis, we observed that SHR exhibited three stages of spontaneous hypertension: prehypertensive (4 weeks), early hypertensive (8 weeks) and established hypertensive (16 weeks). We investigated the expression of $\mathrm{Na}$, K-ATPase $\alpha$ and $\beta$ isoform mRNAs in the left ventricles, aortae and kidneys at each of the three stages of hypertension in SHR and in age-matched WKY.

$\mathrm{Na}, \mathrm{K}$-ATPase $\alpha 1, \alpha 2, \alpha 3$ and $\beta 1$ mRNAs were detected in hearts by Northern blot analysis (Fig. 2). The $\alpha 1$ mRNA signal was detected as a $3.7 \mathrm{~kb}$ band, the $\alpha 2$ mRNA signal was detected as two bands of $5.3 \mathrm{~kb}$ and $3.4 \mathrm{~kb}$, the $\alpha 3$ mRNA was detected as a $3.7 \mathrm{~kb}$ band, and the $\beta 1$ mRNA was detected as a broad band with an approximate size of $2.0 \mathrm{~kb}$. The levels of both $\alpha 1$ and $\alpha 2$ mRNAs re-

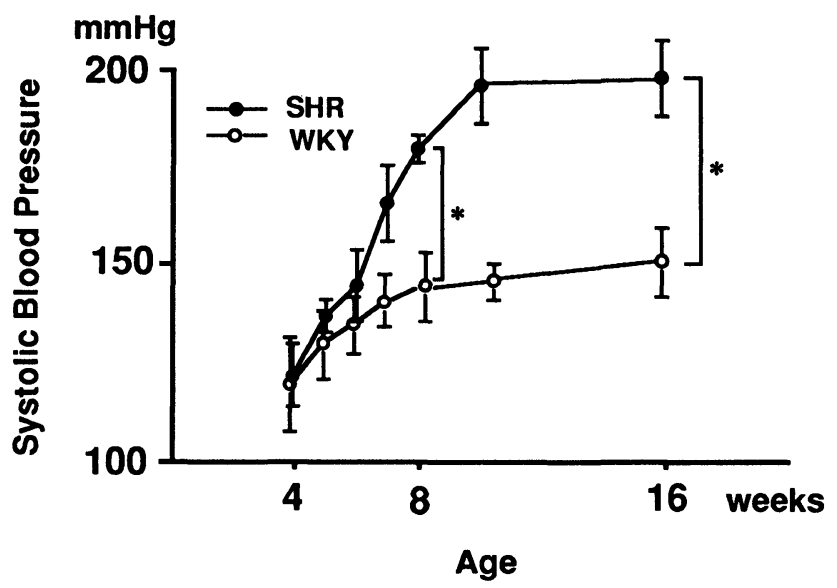

Fig. 1. Systolic blood pressure (SBP) of spontaneously hypertensive rat (SHR) and normotensive Wistar-Kyoto rat (WKY) during 4 to 16 weeks of age. SHR exhibited three stages of spontaneouly hypertension; pre-hypertensive (4 weeks), early hypertensive (8 weeks) and established hypertensive (16 weeks). Data are the mean $\pm S E$ of 12 samples. ${ }^{*} \mathrm{P}<0.01$ compared with age-matched $W K Y$.

mained essentially equivalent in SHR throughout the early ( 8 weeks) and the established periods of hypertension (16 weeks). In contrast, the levels of $\alpha 1$ and $\alpha 2$ mRNAs in WKY increased steadily during the same time period. The neonatal $\alpha 3$ isoform mRNA was detected only in the pre-hypertensive (4 weeks) SHR ventricles. In the quantitative analysis of Northern blot autography, at the age of 4 weeks, there was a significant 4 -fold increase in the amount of $\alpha 1$ and $\alpha 2$ mRNAs in SHR compared with WKY $(3.30 \pm 0.27$ and $4.04 \pm 0.43$, respectively; $n=6, p$ $<0.05$ ) (Fig. 3). The pattern of $\beta 1$ mRNA expression resembled that of $\alpha 1$ or $\alpha 2$ mRNAs, and an approximate 7-fold increase was observed in 4week-old SHR compared with age-matched WKY $(6.71 \pm 1.54 ; p<0.01)$.

The $\alpha 1$ and $\alpha 2$ mRNAs were detected in the aortae (Fig. 4), and their levels in SHR remained essentially equivalent throughout the period of early and established hypertension. In contrast, in WKY, the $\alpha 1$ and $\alpha 2$ mRNAs increased steadily during the same period of time. The $\alpha 3$ mRNA was not detected in the aortae at any stages. As shown in Fig. 5, a significant 5-fold increase in the amount of $\alpha 1$ and $\alpha 2$ mRNAs was observed in prehypertensive SHR compared with age-matched WKY $(4.88 \pm 0.60$ and $5.46 \pm 1.20$, respectively; $n$ $=5, p<0.05)$.

Only the $\alpha 1$ mRNA was detected in the kidneys (Fig. 6). Similar to findings in the hearts and aortae, the level of $\alpha 1$ mRNA in SHR kidneys remained essentially equivalent throughout the 16 weeks, while the level of $\alpha 1 \mathrm{mRNA}$ in WKY increased steadily. At 4 weeks of age, the expression of $\alpha 1 \mathrm{mRNA}$ in SHR showed a significant 2-fold increase compared with that of WKY $(2.39 \pm 0.35 ; n$ $=6, p<0.05)$ (Fig. 7). 


\section{SHR}
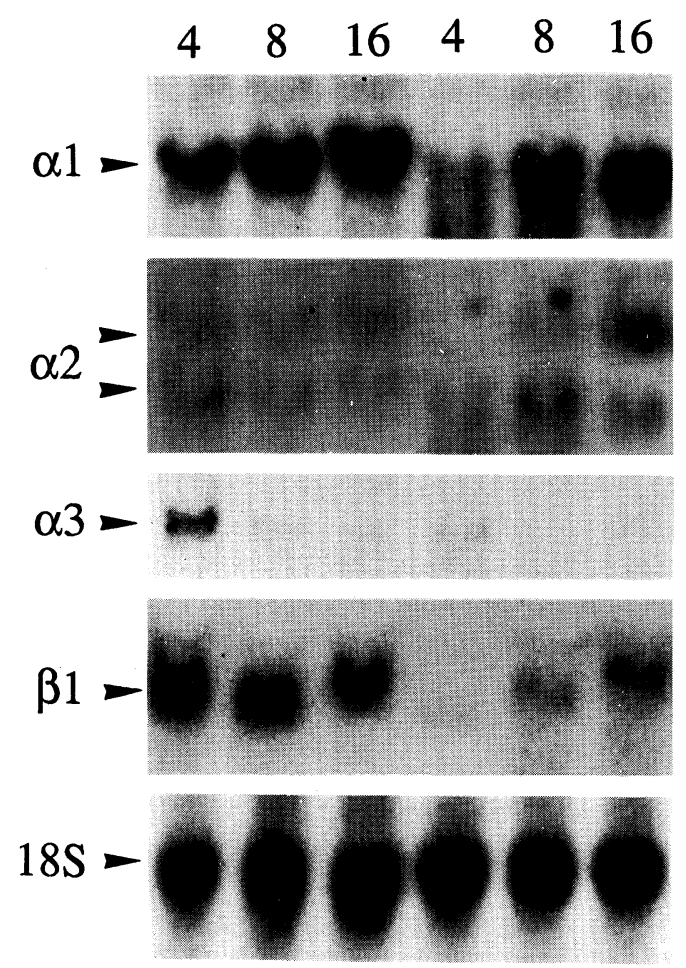

Fig. 2. Expression of $N a, K$-ATPase $\alpha 1, \alpha 2, \alpha 3$ and $\beta 1$ isoform $m R N A s$ in $S H R$ and $W K Y$ ventricles at the age of 4, 8 and 16 weeks. Total RNA was isolated from rat ventricles by GITC-CsCl method. Equal amounts of total RNA $(15 \mu \mathrm{g})$ were size-fractionated by electrophoresis on denaturing $1.0 \%$ agaroselformaldehyde gels and transferred to nylon membranes. Hybridizations were performed with an excess of ${ }^{32} P$-dCTP-labeled $\alpha 1, \alpha 2, \alpha 3$ and $\beta 1$ isoform specific cDNA probes and $18 \mathrm{~S} r R N A$ probe. Filters were washed to a final stringency of $1 x S S P E$ with $0.1 \%$ $S D S$ at $65^{\circ} \mathrm{C}$ and exposed to Kodak XAR-5 film for 1-2 days at $-80^{\circ} \mathrm{C}$ with an intensifying screen.

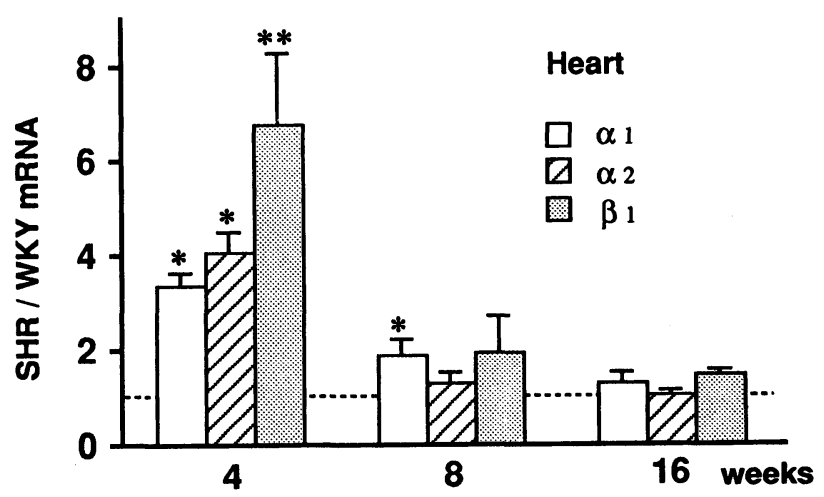

Fig. 3. Relative accumulation of $\alpha$ and $\beta$ isoform mRNAs in ventricles of SHR at three stages of hypertension to that of age-matched WKY. Levels of a mRNAs were determined by Northern blot analysis and quantified by densitometric scanning. Data are the mean \pm SE of 6 samples. ${ }^{*} \mathrm{p}<0.05,{ }^{* *} \mathrm{p}<0.01$.

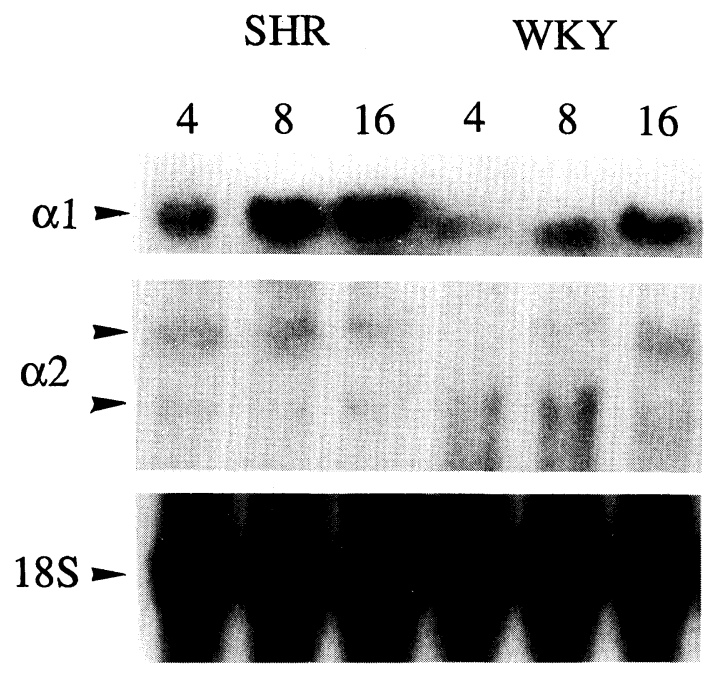

Fig. 4. Expression of $N a, K$-ATPase $\alpha 1$ and $\alpha 2$ isoform $m R N A s$ in SHR and WKY aortae at the age of 4, 8 and 16 weeks. Equal amounts of total RNA $(15 \mu \mathrm{g})$ were sizefractionated on denaturing $1.0 \%$ agarose / formaldehyde gels and transferred to nylon membranes. Filters were hybridized with ${ }^{32} P$-dCTP labeled $\alpha 1$ and $\alpha 2$ specific cDNA probes and $18 S$ rRNA probe.

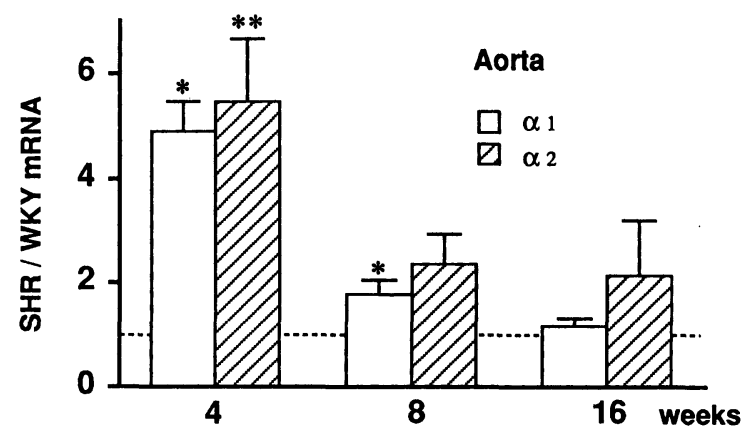

Fig. 5. Relative accumulation of $\alpha$ isoform $m R N A s$ in aortae of SHR at three stages of hypertension to that of age-matched WKY. Levels of a mRNAs were determined by Northern blot analysis and quantified by densitometric scanning. Data are the mean $\pm S E$ of 5 samples. ${ }^{*} \mathrm{p}<$ $0.05,{ }^{* *} \mathrm{p}<0.01$.

\section{Discussion}

Our objective was to determine whether the expression of $\mathrm{Na}$, K-ATPase gene was differentially regulated, and its pattern was altered, during the development of spontaneous hypertension. By Northern blot analysis, we observed the $\alpha 1, \alpha 2$ and $\alpha 3$ isoform mRNA expression in the ventricles, the $\alpha 1$ and $\alpha 2$ isoform mRNA expression in the aortae, and only the $\alpha 1$ isoform mRNA expression in the kidneys. We also revealed an increase in the $\alpha$ isoform mRNA expression in the pre-hypertensive 4week-old SHR tissues, compared with the agematched WKY controls. In the ventricle, the $\beta 1$ mRNA expression was also increased in SHR compared with WKY. Our results further showed that during the normal development of WKY, there was 
SHR
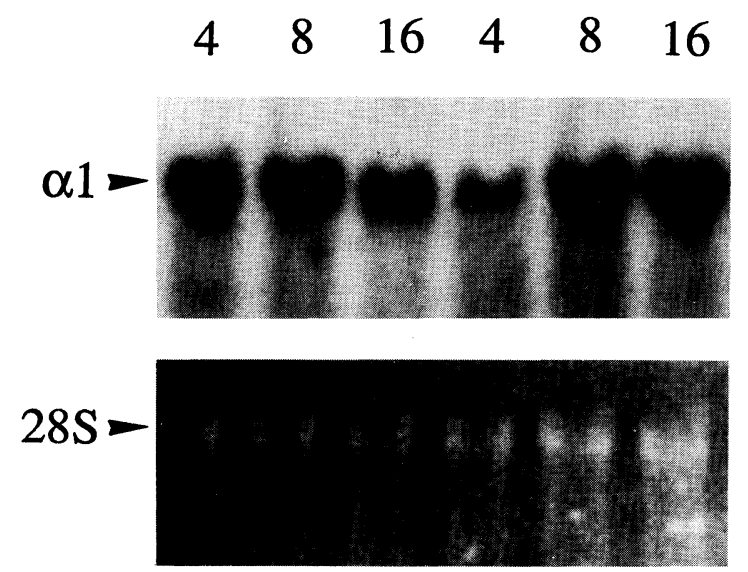

Fig. 6. Expression of $N a, K$-ATPase $\alpha 1$ isoform $m R N A$ in SHR and WKY kidneys at the age of 4, 8 and 16 weeks of age. Total RNA (5 $\mu \mathrm{g})$ was isolated from rat kidneys and size-fractionated by electrophoresis on $1.0 \%$ agarose/ formaldehyde gels and then transferred to nylon membranes. Filters were visualized by UV transillumination $(28$ $S)$ and hybridized with an excess of ${ }^{32} \mathrm{P}-d C T P$ labeled $\alpha 1$ cDNA probe.

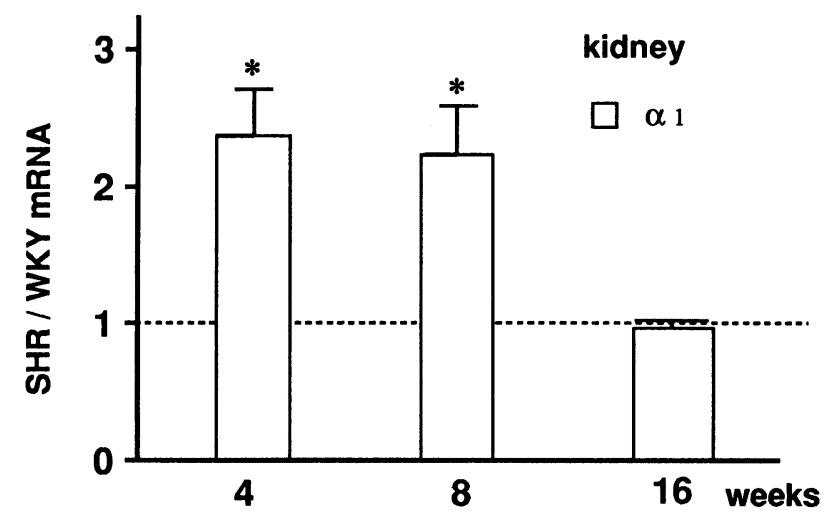

Fig. 7. Relative accumulation of $\alpha 1 \mathrm{mRNA}$ in kidneys of SHR at three stages of hypertension to that of age-matched WKY. Data are the mean \pm SE of 6 samples. ${ }^{*} \mathrm{p}<0.05$.

during the normal development of WKY, there was an increased expression of the $\alpha$ and $\beta$ isoform mRNAs in the hearts, aortae, and kidneys relative to the total cardiac RNA. In SHR, a genetic model of spontaneous hypertension, this developmental pattern of $\mathrm{Na}, \mathrm{K}$-ATPase mRNA expression was significantly altered even before the onset of hypertension. These findings suggest that an abnormality in $\mathrm{Na}, \mathrm{K}$-ATPase gene expression constitutes an early, if not a primary, event in spontaneous hypertension.

Previous studies on the role of $\mathrm{Na}, \mathrm{K}$-ATPase in the pathogenesis of hypertension were based on measurements of $\mathrm{Na}$, K-ATPase activity or of ouabain binding, and conflicting data were obtained
(12-19). Concerning Na, K-ATPase activity in the heart, Godfrained et al. (12) reported that such activity was higher in 7-week-old SHR than in agematched WKY. David-Dufilho et al. (13) also showed that 3-week-old SHR hearts had a greater number of $\mathrm{Na}$, K-ATPase sites than age-matched WKY hearts. In contrast, Chen et al. (14) showed that cardiac $\mathrm{Na}$, K-ATPase activity of SHR was decreased at 6 and 14 weeks of age compared with age-matched WKY. Concerning the aorta, Webb et al. (15) showed that $\mathrm{Na}, \mathrm{K}$-ATPase activity of SHR was significantly increased compared with WKY at 14 to 18 weeks of age. Bruner et al. (16) reported that $\mathrm{Na}, \mathrm{K}$-ATPase activity in the tail arteries of SHR was significantly increased compared with agematched WKY controls. However, Aalkjar et al. (17) reported that the superior mesentric arteries of SHR showed no significant difference in the concentration of $\left[{ }^{3} \mathrm{H}\right]$ ouabain binding sites compared with the age-matched WKY controls. There are also conflicting data on $\mathrm{Na}, \mathrm{K}$-ATPase activity in SHR and WKY kidneys. Cangino et al. (18) reported that $\mathrm{Na}$, K-ATPase activity of 5-week-old SHR kidneys was significantly increased compared with that of agematched WKY kidneys, while Sowers et al. (19) found that $\mathrm{Na}$, K-ATPase activity was significantly reduced in the renal cortex of 9- and 12-week-old SHR compared with that of age-matched WKY. These discrepancies in protein levels may be due to differences in membrane isolation techniques or in enzymatic and ouabain binding assay conditions. Additional factors complicating functional or binding studies are the heterogeneity of the $\alpha$ isoforms expressed and the very low affinity of the rat $\alpha 1$ isoform to ouabain inhibition and binding (6). The heterogeneity of SHR and WKY populations studied may be an additional variable.

It is important to evaluate the difference in the expression of $\mathrm{Na}$, K-ATPase gene between the genetic model of spontaneous hypertension and that of normal rats with experimentally induced hypertension. Herrera et al. (22) showed that both the $\alpha 1$ and $\beta 1$ mRNAs in the hearts were unchanged, while the $\alpha 2$ and $\alpha 3$ mRNAs were de-induced in two models of hypertension produced by angiotensin II infusion or by uninephrectomy and treatment with DOC-salt. These investigators speculated that an elevated intraventricular pressure mediated a down-regulation of $\alpha 2$ mRNA expression via an unknown signal transduction mechanism. In contrast, our results showed that the $\alpha 1$ and $\alpha 2$ mRNA levels were elevated in pre-hypertensive SHR ventricles compared with WKY controls, and remained unchanged in response to elevated blood pressure. These two models would differ with respect to the basal, developmental and pressure-mediated regulation of $\mathrm{Na}$, K-ATPase gene expression. Experimentally induced hypertension in normal rats presents a model of the compensatory regulation of $\mathrm{Na}, \mathrm{K}$-ATPase gene expression in response to an increase in blood pressure. Alternatively, the differing expression of $\alpha 2$ mRNA in SHR may reflect an abnormality in pressure-mediated signal transduction. 
We observed the expression of $\alpha 3$ isoform mRNA only in the ventricles of 4-week-old SHR. The absence of detectable $\alpha 3 \mathrm{mRNA}$ in 4-week-old WKY ventricles is consistent with the developmental switch from the $\alpha 3$ to the $\alpha 2$ isoform mRNA that occurs between 10-14 days in the normal post-natal rat heart $(8)$. The mechanism involved is not known, but most likely involves the developmentally regulated transcriptional regulation of the $\alpha 2$ and the $\alpha 3$ isoform genes. We previously reported that thyroid hormone may contribute to the developmental switching of these $\alpha$ isoforms (20). The phenomenon of the expression of "fetal" protein in pressure-loaded ventricles has been observed with creatine kinase, myosin heavy and light chains, $\alpha$ actin and $\beta$-tropomyosin (23-27). Charlemagne et al. (28) reported that aortic constriction and subsequent ventricular hypertrophy induced the expression of $\mathrm{Na}, \mathrm{K}$-ATPase that exhibited kinetic properties similar to that of newborn rat hearts. However, we found no expression of the neonatal type $\alpha 3$ isoform mRNA in hypertrophic SHR ventricles at 8 and 16 weeks of age.

It is very difficult to determine whether our results reflect causal, primary genetic defect in the expression of $\mathrm{Na}$, K-ATPase gene or the secondary compensation of $\mathrm{Na}$, K-ATPase to elevated blood pressure or other initiating events. The basal and developmental regulation of $\mathrm{Na}$, K-ATPase gene expression is abnormal in SHR, suggesting that a primary defect in $\mathrm{Na}$, K-ATPase gene produces hypertension in this model. Genetic linkage analysis would provide a method of investigating the above hypothesis. Indeed, the $\alpha 1, \alpha 2$ and $\beta 1$ isoform genes have been reported to show restriction fragment length polymorphisms (RFLP) between SHR and WKY (29) and in humans (30-33), supporting the possibility of a primary genetic defect of $\mathrm{Na}, \mathrm{K}$ ATPase gene. However, no previous reports have shown the coordinate segregation of the RFLPs and the development of hypertension. Murine chromosomal mapping studies revealed that the $\alpha 1, \alpha 2$ and $\alpha 3$ isoforms are encoded by separate genes, each of which is located on a different murine chromosome (34). All three $\alpha$ isoform mRNA expression was increased in pre-hypertensive SHR tissues, suggesting that the altered gene expression reflects a compensatory mechanism secondary to other genetic or functional abnormalities.

There are numerous reports showing an abnormal increase in intracellular $\mathrm{Na}^{+}$levels in SHR tissues due to either an increased $\mathrm{Na}^{+}$flux or a decreased $\mathrm{Na}^{+}$efflux that requires an increased level of $\mathrm{Na}, \mathrm{K}-$ ATPase expression. Friedman et al. (9) reported that the tail arteries of 26- to 28-week-old SHR showed increased accumulation of $\mathrm{Na}^{+}$compared with that of the control rats. Pickar et al. (10) also described an increased $\mathrm{Na}$ content in skeletal muscles of 24- to 28-week-old SHR compared with that of age-matched WKY. Zidek et al. (11) found that the intracellular $\mathrm{Na}^{+}$activity of SHR erythrocytes was significantly increased compared with that of Wistar rat erythrocytes. Mendonca et al. (35) reported that $\mathrm{Na}^{+}$extrusion of erythrocytes was im- paired in 4-week-old SHR compared with that of WKY at the same age. Alterations in intracellular $\mathrm{Na}^{+}$levels can induce a change in $\mathrm{Na}$, K-ATPase gene expression, as in our previous study showing that $\mathrm{Na}^{+}$induces a transient increase in the $\alpha$ and $\beta$ isoform mRNA expression in cultured neonatal rat cardiocytes (36).

The endogenous digitalis-like factor may also affect the expression of $\mathrm{Na}$, K-ATPase gene. Goto et al. (37) reported that the plasma level of the digitalis-like factor was increased in patients with hypertension. Tsuda et al. (38) also observed that the plasma level of the digitalis-like factor was higher in hypertensive than in normotensive subjects. Inhibition of $\mathrm{Na}$, K-ATPase by this digitalis-like factor could increase intracellular $\mathrm{Na}^{+}$levels and stimulate $\mathrm{Na}$, K-ATPase gene expression (35). In addition, other hormones such as epinephrine, angiotensin II or aldosterone, which are elevated in the plasma of SHR or hypertensive subjects, may be involved in the increased expression of $\mathrm{Na}, \mathrm{K}$ ATPase gene in SHR tissues $(39,40)$.

In the present study, we observed that the expression of $\mathrm{Na}, \mathrm{K}$-ATPase $\alpha$ and $\beta$ isoform mRNAs was increased in the early, pre-hypertensive ventricles, aortae and kidneys of SHR. These results do not rule out an additional regulation at the translational and post-translational levels culminating in a functional $\mathrm{Na}$, K-ATPase. However, our data suggest that an abnormality in the expression of $\mathrm{Na}, \mathrm{K}$ ATPase gene is an early, if not a primary, event in the development of hypertension in SHR.

\section{Acknowledgements}

We thank Drs. K. Nagano (Jichi Medical School) and R.M. Medford (Emory University School of Medicine) for their helpful discussion.

\section{References}

1. Shull GE, Greeb J, Lingrel JB: Molecular cloning of three distinct forms of the $\mathrm{Na}^{+}, \mathrm{K}^{+}$-ATPase $\alpha$-subunit from rat brain. Biochemistry 1986, 25: 8125-8132.

2. Shull MM, Lingrel JB: Multiple genes encode the human $\mathrm{Na}^{+}, \mathrm{K}^{+}$-ATPase catalytic subunit. Proc Natl Acad Sci, USA 1987, 84: 4039-4043.

3. Young RM, Shull GE, Lingrel JB: Multiple mRNAs from rat kidney and brain encode a single $\mathrm{Na}^{+}, \mathrm{K}^{+}-$ ATPase $\beta$ subunit protein. J Biol Chem 1987, 262: 4905-4910.

4. Martin-Vasallo D, Dackowski W, Emanuel JR, Levenson R: Identification of a putative isoform of the Na, K-ATPase $\beta$ subunit. J Biol Chem 1989, 264: 4613-4618.

5. Kawakami $K$, Nojima $H$, Ohta $T$, Nagano $K$ : Molecular cloning and sequence analysis of human $\mathrm{Na}$, K-ATPase $\beta$-subunit. Nucleic Acids Res 1986, 14: 2833-2844.

6. Sweadner KJ, Farshi SK: Rat cardiac ventricles have two $\mathrm{Na}^{+}, \mathrm{K}^{+}$-ATPase with different affinities for ouabain: developmental changes in immunologically different catalytic subunits. Proc Natl Acad Sci USA 1987, 84: 8404-8407.

7. Adams RJ, Schwartz A, Grupp G, et al.: High-affinity ouabain binding site and low-dose positive inotro- 
pic effect in rat myocardium. Nature 1982, 296: 167169.

8. Orlowski J, Lingrel JB: Tissue-specific and developmental regulation of rat $\mathrm{Na}, \mathrm{K}$-ATPase catalytic $\alpha$ isoform and $\beta$ subunit mRNAs. J Biol Chem 1988, 263: $10436-10442$.

9. Friedman SM: Evidence for enhanced sodium transport in the tail artery of the spontaneously hypertensive rat. Hypertension 1979, 1: 572-582.

10. Pickar JG, Atrakchi A, Gray SD, Carlsen RC: Apparent upregulation of $\mathrm{Na}, \mathrm{K}$ pump sites in SHR skeletal muscle with reduced transport capacity. Clin Exper Hypertens 1991, A13: 645-652

11. Zidek W, Vetter H, Zumkley H, Losse H: Intracellular cation activities and concentrations in spontaneously hypertensive and normotensive rats. Clin Sci 1981, 61: 41 S-43 S.

12. Godfrained T, Noel F: Sodium activation of heart $\left(\mathrm{Na}^{+}+\mathrm{K}^{+}\right)$-ATPase from normotensive and spontaneously hypertensive rats. Arch Int Pharmacodyn Ther 1980, 245: 139-144.

13. David-Dufilho M, Devynck MA, Beugras JP, Meyer P: Quantitative changes in cardiac $\mathrm{Na}^{+}, \mathrm{K}^{+}$-adenosine triphosphatase of spontaneously hypertensive rats. J Cardiovasc Pharmacol 1984, 6: 273-280.

14. Chen CC, Lin-Shiau SY: Decreased $\mathrm{Na}^{+}-\mathrm{K}^{+}-\mathrm{ATPase}$ activity and $\left[{ }^{3} \mathrm{H}\right]$ ouabain binding sites in various tissues of spontaneously hypertensive rats. Eur J Pharmacol 1986, 122: 311-319.

15. Webb RC, Bohr DF: Potassium relaxation of vascular smooth muscle from spontaneously hypertensive rats. Blood Vessels 1979, 16: 71-79.

16. Bruner CA, Myers JH, Sing CF, Pentti TJ, Webb $\mathrm{RC}$ : Genetic basis for altered vascular responses to ouabain and potassium-free solution in hypertension. Am J Physiol 1986, 251: H1276-H1282.

17. Aalkjar C, Kjeldsen $\mathrm{K}$, Norgaard $\mathrm{A}$, Clausen $\mathrm{T}$, Mulvany MJ: Ouabain binding and $\mathrm{Na}^{+}$content in resistance vessels and skeletal muscles of spontaneously hypertensive rat and $\mathrm{K}^{+}$-depleted rats. Hypertension 1985, 7: 277-286.

18. Cangino JL, Rodriguez-Sargent C, Opava-Stitzer S, Martinez-Maldonado $\mathrm{M}$ : Renal $\mathrm{Na}^{+}-\mathrm{K}^{+}-\mathrm{ATPase}$ in weanling and adult spontaneously hypertensive rats. Proc Soc Exp Biol Med 1984, 177: 240-246.

19. Sowers JR, Beck F, Stern N, Raghavan SRV: Reduced sodium-potassium dependent ATPase and its possible role in the development of hypertension in spontaneously hypertensive rats. Clin Exp Hypertens 1983, A5: 71-86.

20. Kamitani T, Ikeda U, Muto S, et al: Regulation of $\mathrm{Na}$, K-ATPase gene expression by thyroid hormone in rat cardiocytes. Circ Res 1992, 71: 1457-1464.

21. Chirgwin JM, Przybyld AE, Wacdonald RJ: Isolation of biologically active ribonucleic acid from sources enriched in ribonuclease. Biochemistry 1979, 18: 5249-5299.

22. Herrera VLM, Chobanian AV, Ruiz-Opazo N: Isoform-specific modulation of $\mathrm{Na}^{+}, \mathrm{K}^{+}$-ATPase $\alpha$ subunit gene expression in hypertension. Science 1988, 241: 221-223.

23. Rovner AS, McNally EM, Leinwand LA: Complete cDNA sequence of rat atrial myosin light chain-1: pattern of expression during development and with hypertension. Nucleic Acid Res 1990, 18: 1581-1586.

24. Lompre AM, Schwartz K, d'Albis A, Thiem NL, Lacombe G, Swynghedauw B: Myosin isoenzyme distribution in chronic heart overload. Nature 1979, 282: 105-107.

25. Izumo $\mathrm{S}$, Lompre $\mathrm{AM}$, Matsuoka $\mathrm{R}$, et al : Myosin heavy chain messenger RNA and protein isoform during cardiac hypertrophy: interaction between hemodynamic and thyroid hormone-induced signals. J Clin Invest 1987, 79: 970-977.

26. Schiaffino S, Samuel JL, Sasson D, et al: Nonsynchronous accumulation of $\alpha$-skeletal actin and $\beta$ myosin heavy chain mRNAs during early stages of pressure-overload-induced cardiac hypertrophy demonstrated by in situ hybridization. Circ Res 1989 , 64: $937-948$

27. Schwartz K, de la Bastie D, Bouveret $\mathrm{P}$, Oliviero $\mathrm{P}$, Alonso S, Buckingham $\mathrm{M}$ : $\alpha$-skeletal muscle actin mRNAs accumulate in hypertrophied adult rat hearts. Circ Res 1986, 59: 551-555.

28. Charlemagne D, Maixent JM, Preteseille M, Lelievre LG: Ouabain binding sites and $\left(\mathrm{Na}^{+}, \mathrm{K}^{+}\right)$-ATPase activity in rat cardiac hypertrophy. J Biol Chem 1986, 261: $185-189$.

29. Nojima H, Yagawa Y, Kawakami K: The Na, KATPase alpha 2 subunit gene displays restriction fragment length polymorphism between the genomes of normotensive and hypertensive rats. $J$ Hypertens 1988, 7: 937-940.

30. Shull MM, Pugh DG, Lingrel JB: The human Na, KATPase $\alpha 1$ gene; characterization of the 5'-flanking region and identification of a restriction fragment length polymorphism. Genomics 1990 , 6: 451-460.

31. Shull MM, Pugh DG, Lingrel JB: Characterization of the human $\mathrm{Na}, \mathrm{K}$-ATPase $\alpha 2$ gene and identification of intragenic restriction fragment length polymorphisms. J Biol Chem 1989, 264: 17532-17543.

32. Masharani U, Frossard PM: Msp I and Hind III restriction fragment length polymorphism at the human $\mathrm{Na}, \mathrm{K}$-ATPase $\beta$-subunit (ATP1 B) gene locus. Hum Genet 1988, 80: 308.

33. Shull MM, Hassebain D, Loggie $\mathbf{J}$, et al: Discordant segregation of $\mathrm{Na}^{+}, \mathrm{K}^{+}$-adenosine triphosphatase alleles and essential hypertension. J Hypertens 1992 , 10: $1005-1010$.

34. Kent RB, Fallows DA, Geissler E, et al: Genes encoding $\alpha$ and $\beta$ subunits of the Na, K-ATPase are located on three different chromosomes in the mouse. Proc Natl Acad Sci, USA 1987, 84: 5369-5372.

35. Mendonca MD, Grichois ML, Garay RP, Sassard J, Ben-Ishay D, Meyer P: Abnormal net $\mathrm{Na}^{+}$and $\mathrm{K}^{+}$ fluxes in erythrocytes of three varieties of genetically hypertensive rats. Proc Natl Acad Sci, USA 1980, 77: 4283-4286.

36. Yamamoto K, Ikeda U, Seino Y, et al: Regulation of $\mathrm{Na}, \mathrm{K}$-ATPase gene expression by sodium ions in cultured neonatal rat cardiocytes. J Clin Invest 1993, 92: 1889-1895.

37. Goto A, Yamada K, Ishii M, Sugimoto K: Digitalislike activity in human plasma: relation to blood pressure and sodium balance. Am J Med 1990, 89: 420-425.

38. Tsuda K, Shima H, Takeda J, Kimura K, Nishio I, Masuyama Y: The role of endogenous $\mathrm{Na}^{+}, \mathrm{K}^{+}$-adenosine triphosphatase inhibitory factor in the regulation of membrane fluidity of erythrocytes in essential hypertension. J Hypertens 1992, 10: 657-661.

39. Ikeda U, Hyman R, Smith TW, Medford RM: Aldosterone-mediated regulation of $\mathrm{Na}^{+}, \mathrm{K}^{+}$-ATPase gene expression in adult and neonatal rat cardiocytes. J Biol Chem 1991, 266: 12058-12066.

40. Oguchi A, Ikeda U, Kanbe $\mathrm{T}$, et al: Regulation of $\mathrm{Na}, \mathrm{K}$-ATPase gene expression by aldosterone in vascular smooth muscle cells. Am J Physiol 1993 , 265: H1167-H1172. 